УДК 378.147:355.232

Леонід Олійник, кандидат педагогічних наук, старший науковий співробітник, Національний університет оборони України імені Івана Черняховського, м. Київ

ORCID ID 0000-0002-7375-1281

DOI: $10.33099 / 2617-1775 / 2019-02 / 128-138$

\title{
АКТИВІЗАЦІЯ НАВЧАЛЬНО-ПІЗНАВАЛЬНОЇ ДІЯЛЬНОСТІ МАГІСТРАНТІВ В СИСТЕМІ ВИЩОЇ ВІЙСЬКОВОЇ ШКОЛИ
}

У статті визначаються напрямки дослідження форм та методів активізаиії навчально-пізнавальної діяльності на підставі аналізу навчання магістрантів в умовах університетської освіти. Аналізуючи впровадження інноваційних технологій у вивчення навчальних дисциплін встановлено, щчо особливо актуальними $i$ ефективними $\epsilon$ комунікативно-діалогова та інформачійна технологї̈ навчання.

Ключові слова: навчання; магістранти; інновачійні методи навчання; навчальнопізнавальна діяльність; комунікативно-діалогова технологія; інформаційна технологія.

Постановка проблеми. Збереження миру сьогодні $\epsilon$ актуальною проблемою для усіх країн світу. Події 2014-2019 років в Україні, анексія Криму та військові дії на Сході України поставили під загрозу існування держави, забезпечення іiі цілісності, безпеки і суверенітету, але Майдан Гідності, героїзм захисників України змінили самих українців, сприяли згуртуванню української нації. Сучасний стан Збройних Сил України та реалії XXI століття вимагають якісно нових підходів до підготовки офіцерського складу, організації освітнього процесу, налагодження i впровадження організаційних, сучасних технологій, які могли б забезпечувати не тільки виконання завдань реформування військової освіти, а й сприяти всебічному розвитку суб'єктів навчання та їх успішній самореалізації в соціальному та військовопрофесійному середовищі.

Реформування військової освіти спонукає до переосмислення бачення, що стосується управління навчальною діяльністю магістрантів, пошуку нових форм та методів навчання слухачів. Важливим напрямком вдосконалення технологій навчання у вищому військовому закладі $\epsilon$ застосування методів активізації навчально-пізнавальної діяльності магістрантів.

Аналіз останніх досліджень. За останній час форми інтерактивного навчання набули досить широкого розповсюдження в теорії та практиці освіти у Західній Свропі та США. За даними досліджень фахівців, які порівняли різні методи та моделі навчання слухачів, було виявлено, що найменших результатів можна досягнути за умов пасивного навчання.

Як зазначає більшість фахівців, модернізація національної системи освіти, складність масштабного реформування Збройних Сил України актуалізує проблему формування творчої особистості військового професіонала, здатного ефективно розв’язувати складні військово-професійні 
проблеми, та передбачає новий підхід до навчання магістрантів, спрямований на подолання кризи в освіті, яка проявляється, передусім, у невідповідності рівня знань запитам особистості, суспільним потребам і світовим стандартам, у знеціненні престижу військової служби, освіченості та інтелектуальної діяльності.

Необхідно дотримуватися і безперервно удосконалювати, перш за все, наступні найважливіші складові освітнього процесу:

навчальне середовище;

1) особистість науково-педагогічного працівника;

2) зміст навчання;

3) повсякденну роботу і старанність тих, хто навчається [2]

Актуальність дослідження полягає у визначенні чому i як навчати магістрантів в умовах університетської освіти? Ці питання, в усій їхній складності та вагомості, завжди стояли і нині стоять перед вищою військовою школою. Йдеться про те, що ретельно відібраний із різноманітних наукових джерел і дидактично опрацьований навчальний матеріал має забезпечити якісну підготовку військових фахівців. Для цього зміст військової освіти слід постійно оновлювати відповідно до вимог сучасної військової практики, науковотехнічного і суспільного прогресу, беручи до уваги те, що ми живемо у світі змін, які дедалі прискорюються.

Аналіз наукових розробок, які пов'язані з питаннями навчання військових фахівців, що здійснено такими вченими як Нещадим М. I. [1], Ройлян В. О. [4], Ягупов В. В. [5] та ін. дає змогу зробити висновок, що безпосередньо проблема підготовки військових фахівців досліджена досить глибоко, але в той же час шляхи та проблеми активізації навчально-пізнавальної діяльності магістрантів в умовах університетської освіти досліджені ще недостатньо.

Метою статті $\epsilon$ визначення і подання окремих інноваційних методів навчання магістрантів. Значна увага приділяється розкриттю сутності та особливостей інноваційних технологій, зокрема, комунікативно-діалогової, дискусійної, ігрової. Теоретичний аналіз науково-методичної літератури та багаторічний досвід проведення навчальних занять дають підстави стверджувати, що саме інтерактивні методи навчання $\epsilon$ однією із важливих сучасних технологій у навчанні магістрантів в умовах університетської освіти.

Виклад основного матеріалу. Активізація навчальної діяльності магістрантів забезпечується виконанням цілої системи психолого-педагогічних умов, а саме: чіткого визначення цілей освітнього процесу, їх усвідомлення науково-педагогічними працівниками і слухачами, приведенням у відповідність до цілей змісту навчання, введенням такої методики навчання, яка створила б максимальні можливості для прояву ініціативи, самостійності i творчості особистості, забезпеченням якісного контролю за навчально-пізнавальною діяльністю слухачів.

Удосконалення процесу навчання залежить від умінь науковопедагогічного працівника планувати, організовувати, цілеспрямовано управляти пізнавальною діяльністю та активізувати іiі. 
Складовими успіху при цьому є: опора на психолого-педагогічні знання і особливості освітнього процесу; поєднання у методиці викладання (навчання) основ психології і дидактики; створення власної методики на основі використання закономірностей системи психологічних і дидактичних знань.

Елементами, що підсилюють активізацію й управління навчанням магістрантів можуть бути: навчальні ігри; дискусії; практикуми із розробленими збірниками завдань, які орієнтовані на вирішення практично значимих результатів у підготовці військових фахівців, що створюють можливість здійснювати індивідуальний підхід у навчанні магістрантів; організація шляхів розв'язання завдань груповим методом; проведення пресконференції (специфіка кожного предмету полягає у кількості фактів і назв). Важливо виділяти основне у навчальному матеріалі i не спонукати опрацьовувати другорядне; дозування навчального матеріалу, щоб забезпечувати зміну видів діяльності, що сприятиме підтриманню уваги i працездатності суб'єктів навчання.

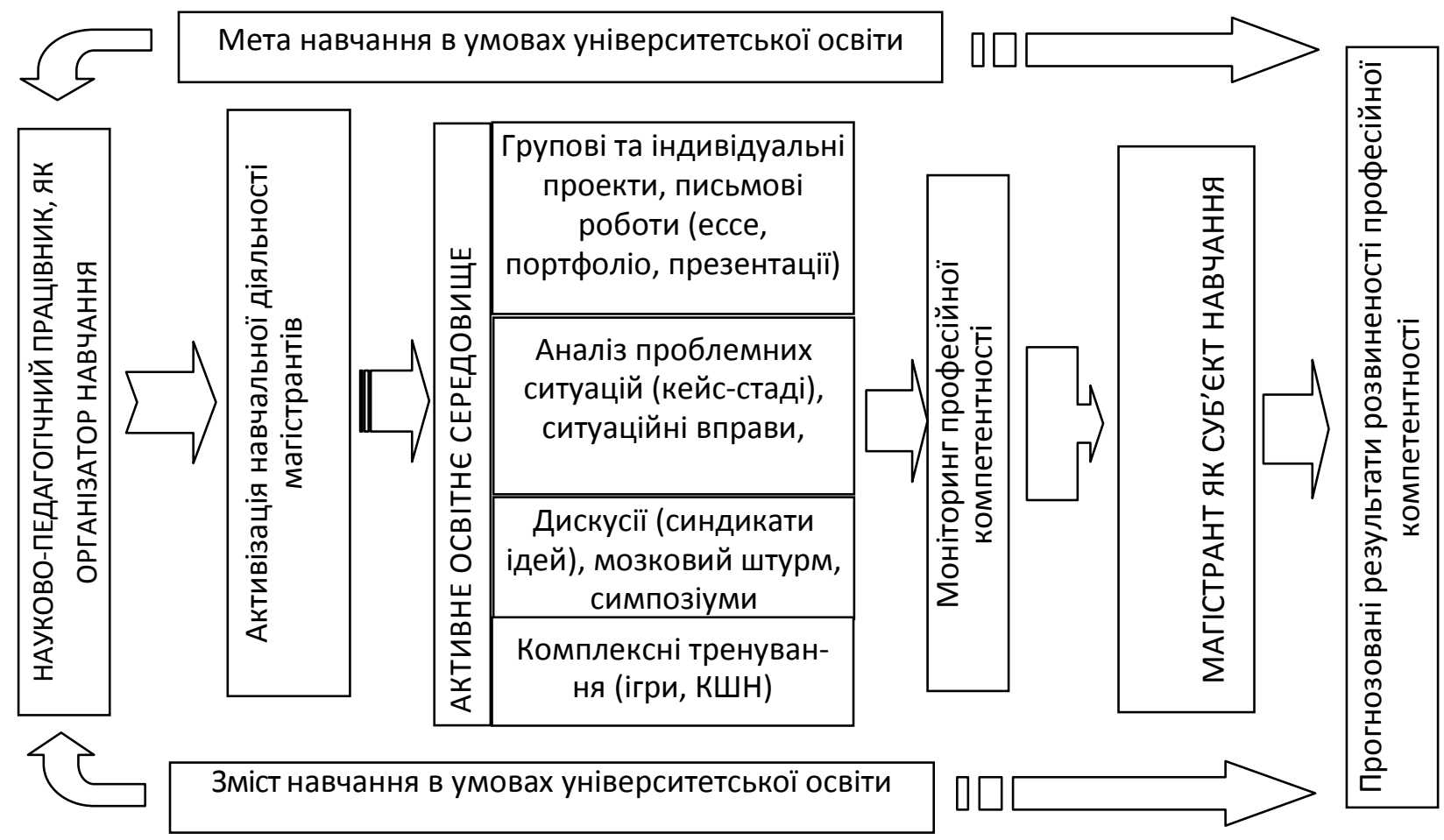

Рис. Модель активізації навчально-пізнавальної діяльності магістрантів в системі вищої військової школи

Шляхами активізації пізнавальної діяльності в освітньому процесі є: розкриття і встановлення зв'язків і залежностей при поясненні сутності теорій, законів, понять; розкриття деталей; образні порівняння, описи, цікаві відомості про них; використання ілюстрацій з журналів, таблиць, кадрів 3 навчальних фільмів; організація роботи з підручниками; використання прийому викладу тематичного матеріалу за аналогією; використання в освітньому процесі проблемних запитань; створення i використання проблемних ситуацій; розв'язування завдань за аналогією; наведення прикладів вирішення завдань із 
досвіду проведення операції Об'єднаних сил (АТО); ділова гра; пресконференція: підбирають матеріали 3 газет, журналів, брошур 3 різних напрямків: військового, технічного, гуманітарного.

Важливо забезпечити раціональне співвідношення теоретичної i практичної діяльності магістрантів: теоретичний матеріал поєднується 3 виконанням різноманітних завдань (на будь-якому етапі навчального заняття можна організувати диференційований підхід при загальній, груповій та індивідуальній роботі слухачів); прийом порівняння підсилює пізнавальну

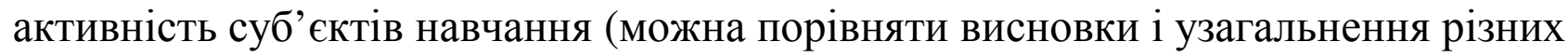
осіб, що навчаються, урізноманітнити форми перевірки знань та умінь на основі порівняння, наприклад, рецензування однієї й тієї роботи різними експертами 3 числа суб' єктів навчання, з проведенням оцінки з письмовою її аргументацією); по закінченні вивчення тем, модулів, чи розділів, провести узагальнення у формі вікторини, змагання, умовних бойових ситуацій, конкурсів, де крім знань виявляють кмітливість та командирські здібності; програмованих завдань 3 теорії і практики використання пізнавальної діяльності військових керівників; урізноманітнення методик перевірки знань (формалізованих на бланках, швидких за перевіркою, розроблених на індивідуальних картках, словесних i знакових завдань); зв'язок теоретичного матеріалу з життям (коротка розповідь про видатних вчених певної галузі науки); використання в освітньому процесі навчально-методичних матеріалів.

Практичні роботи спрямовані на: застосовування теоретичних знань на практиці, сприяння глибокому осмисленню вивченого матеріалу магістрантами та надання допомоги усвідомленого його засвоювання; формування практичних навичок і умінь; на етапі підготовки і тренування: кількість завдань і ступінь складності визначається в залежності від рівня індивідуальної підготовки слухачів. Серед них: пошукові завдання, які потребують роботи з текстом, ілюстраціями, таблицями підручника, топографічними, історичними картами, формулами; зразки завдань і алгоритми їх вирішення; проблемний виклад матеріалу; зразки логіки аналізу інформації, іiї творче осмислення.

Активізації розумової діяльності сприяє: самостійному вивченню матеріалу параграфів і складання запитань, на які в тексті немає відповіді; умінню ставити запитання (ведуть до вдумливого читання тексту, осмисленні його); самостійна робота 3 текстом сприяє самоконтролю, яку необхідно урізноманітнювати: виділяти опорні слова, розробляти схеми, вести короткі записи.

Опорними служать слова, що визначають основний зміст, розкривають суть явища або процесу.

Приклади роботи з текстом (підручником, словниками, монографіями, навчальними посібниками, інше): використовуючи текст дайте визначення; прочитайте текст ...і на основі визначених понять поясніть...; опрацюйте текст і назвіть...; виділіть у тексті опис особливостей...; виявіть, які зв'язки ... вказуються у тексті, а які слід визначити самостійно. 
Ведення конспектів сприяє осмисленню інформації, виділенню у змісті інформації найголовнішого, вчить логічно мислити, узагальнювати і робити висновки, запам'ятовувати і відтворювати вивчене; включення в самостійну роботу завдань, що орієнтують на пізнавальну діяльність 3 текстом, картографічним матеріалом, статистичними матеріалами періодичних видань (формує навички роботи 3 різними джерелами інформації), технічною апаратурою, інструкціями, директивними документами; застосування нестандартних методів навчання (здійснює підготовку до самостійної праці i життя); розв'язання пізнавальних завдань, орієнтованих на розвиток усіх видів пам'яті (образна пам'ять, рушійна, словесно-логічна, емоційна, короткочасна, довготривала, недовільна, довільна); контроль шляхом оперативного спілкування; виділення резерву часу для індивідуальної роботи з “сильними" i “слабкими” суб'єктами навчання.

Одним із основних шляхів ефективного вирішення завдань навчання магістрантів в умовах університетської освіти $є$ переорієнтація на якісно нову технологію освітнього процесу, яка передбачає запровадження принципів нового педагогічного мислення. У процесі дослідження з'ясовано, що інноваційні технології перетворюють характер навчання відносно таких його суттєвих якостей, як цільова орієнтація, характер взаємодії суб'єктів навчання. Аналізуючи впровадження інноваційних технологій у вивчення навчальних дисциплін, встановлено, що особливо актуальними i ефективними $\epsilon$ комунікативно-діалогова та інформаційна технології. Застосування засобів інформаційної технології, а саме сучасних проекційних приладів, відео та комп'ютерної техніки, значно підвищують ефективність лекційних занять та сприяють вирішенню проблеми активізації пізнавальної діяльності магістрантів. Зокрема використання відеофрагментів, в яких відтворюються різноманітні навчальні ситуації, що вимагають аналізу і відповідних обгрунтованих висновків, дають змогу ефективно проводити теоретичні заняття, забезпечивши атмосферу творчої співпраці лектора із слухацькою аудиторією.

На наш погляд, запроваджувати їх в практику навчання, необхідно починати із серйозної перебудови лекційного курсу. Теоретичний постулат про проблемність лекції звільняє науково-педагогічного працівника від необхідності обов'язкового тлумачення всієї інформації, закладеної у робочій навчальній програмі. Це дає змогу науково-педагогічному працівнику застосувати комунікативно-діалогову технологію навчання, коментувати проблему в такий спосіб, щоб без самостійно розробленої конкретизації іiі різнобічних аспектів не можна було б виконати практичні завдання. Тобто магістрант поставлений в умови, які передбачають необхідність самостійно здобувати ту частину знань, яка в поєднанні 3 аудиторною програмою становить єдине ціле. Визначена організація навчального курсу передбачає відмову слухачів від заформалізованих схем і трафаретів, усвідомлення навчальної потреби творчого сприйняття матеріалу і наукового пошуку, який повинен стати органічною складовою професійної самоосвіти. Численність $\mathrm{i}$ 
розмаїття активних форм роботи, які можна застосувати на заняттях 3 навчальних дисциплін, вимагає їх певної (умовної) типології. Нами використовуються такі типи робіт: творчі завдання вербального та практичного характеру; складання i аналіз структурно-логічних і опорно-інформаційних схем, конспектів занять, заповнення текстових таблиць; моделювання різноманітних навчальних ситуацій; імітаційні та ділові ігри; навчальні дискусії. До творчих завдань вербального характеру належать такі, які спрямовують слухачів на підготовку невеличких фрагментів викладу матеріалу. У ході такої тренувальної роботи поступово формуються професійні навички майбутнього фахівця, зростає інтерес до роботи, розкриваються якості слухача. Інколи творчі завдання вербального характеру дещо ускладнюються. Слухачі готують не тільки тексти повідомлень, а й наочність, на основі якої ці повідомлення розкриваються: схеми, таблиці, графіки, презентації, ессе. Серед активних форм роботи на практичних заняттях найголовнішими, безумовно, $\epsilon$ ділові ігри, в процесі проведення яких створюються ситуації практичної діяльності слухача, які повністю імітують професійну діяльність. Викладач виконує роль організатора процесу навчання, координатора, консультанта. Він спрямовує діяльність слухачів, допомагає розробити схему пошуку, контролює роботу групи на проміжних етапах. Слухачі ж, у свою чергу, працюють над навчальним завданням у групах, обговорюють його, шукаючи вирішення поставлених завдань. Подібна співпраця слухачів дозволяє вирішити складні питання набагато швидше та ефективніше. Розв'язуючи спільно навчальну проблему, група опановує співробітництво та проявляє співтворчість - всі працюють один для одного. Відбувається обмін знаннями, думками та ідеями. В інтерактивній групі навіть слабші у навчанні слухачі без дискомфорту приймають активну участь в обговоренні та прийняті рішення стосовно поставлених завдань. Взаємодія та співпраця між слухачами є пріоритетом у цьому методі навчання.

Активні методи навчання - це сукупність прийомів i способів психологічно-педагогічного впливу на об'єкти навчання, які порівняно 3 традиційними методами навчання, у першу чергу спрямовані на розвиток у них творчого самостійного мислення, активізацію навчально-пізнавальної діяльності, формування навичок і вмінь нестандартного розв'язання військовопрофесійних проблем і вдосконалення навичок професійного спілкування [5].

Активні методи навчання часто використовуються під час групових занять. Проблемні завдання, які вирішуються слухачами у ході таких навчальних занять, дозволяють не тільки підвищити рівень засвоєння навчального матеріалу, але й сприяють формуванню фахових навичок офіцерів за посадою та здатних самостійно і творчо вирішувати завдання у конкретно запропонованих практичних умовах.

Як свідчать результати дослідження практичних і семінарських занять, поширення отримала також і дискусійна технологія. Вона забезпечує кращі результати там, де інші методи виявляються менш ефективними. Серед форм їі проведення: "Круглий стіл” - бесіда, в якій бере участь невелика кількість 
магістрантів, відбувається обмін думками як між ними, так із аудиторією; “засідання експертної групи”, на якому спочатку обговорюється намічена проблема, а потім учасниками висловлюються власні пропозиції; “симпозіуми” - обговорення,в процесі якого учасники виступають 3 повідомленнями, що представляють їхні точки зору, після чого відповідають на запитання, які побудовані на основі попередніх виступів та їх спростувань з боку учасників представників двох суперницьких команд. Організація і проведення дискусії вимагають чималих знань, зусиль і часу, як з боку науково-педагогічного працівника, так і з боку слухачів. Тому необхідна ретельна підготовка до неї. На практичних заняттях необхідно методично готувати слухачів до проведення дискусій, акцентуючи увагу на тому, що навчитися дискутувати, не перетворюючи цей процес у прості суперечки, які не мають логічного завершення, - це тривала, кропітка робота. На підготовчому етапі оголошується тема i пропонується перелік відповідної літератури 3 метою розширення світогляду слухачів 3 обраної проблеми i формування уміння самостійно працювати з різноманітними джерелами інформації. Другий етап проведення дискусії - це керований процес, науково-педагогічний працівник спрямовує його в потрібне русло, коригує матеріал, яким оперують слухачі. На завершення обов'язково разом із ними підводить підсумок, акцентуючи увагу на правильних, науково-обгрунтованих позиціях щодо вирішення запропонованої проблеми.

Аналіз конкретних ситуацій - це ефективний метод активізації навчально-пізнавальної діяльності магістрантів в умовах університетської освіти. Названий метод характеризується такими ознаками: наявність конкретної ситуації; розробка групою (підгрупою чи індивідуально) варіантів вирішення ситуації; захист розроблених варіантів вирішення ситуацій 3 наступним їх опануванням; підведення підсумків та оцінка результатів заняття.

Існує декілька видів ситуацій:

1. Ситуація-проблема являє собою описання реальної проблеми, яка потребує вирішення. Мета: знайти вирішення ситуації або прийти до висновку про неможливість пї вирішення.

2. Ситуація-оцінка описує положення, вихід із якого вже знайдено. Мета: провести критичний аналіз прийнятих рішень, зробити висновок 3 приводу поданої ситуації та їі вирішення.

3. Ситуація-ілюстрація являє ситуацію та, пояснюючи причини ii виникнення, описує процедуру їі вирішення. Мета: оцінити ситуацію в цілому, провести аналіз іï вирішення, сформулювати питання, виразити погодження непогодження.

4. Ситуація-попередження описує застосування вже прийнятих раніше рішень, у зв’язку 3 цим ситуація носить тренувальний характер, слугує ілюстрацією до тієї чи іншої теми. Мета: проаналізувати дані ситуації, знайти рішення з використанням отриманих теоретичних знань.

Такий метод навчання спрямований на розвиток уміння аналізувати складні завдання, здатності приймати рішення [3, с. 53]. 
Розігрування ролей (рольова гра) - імітаційний ігровий метод активного навчання магістрантів. Для нього характерні такі ознаки: наявність завдання (проблеми) та розподілу ролей між слухачами; взаємодія між слухачами. Кожний з них, згідно зі своєю роллю, може погодитися або не погодитися 3 думкою інших слухачів, висловлювати власну думку тощо; введення науковопедагогічним працівником у процесі заняття коригувальних умов. Так, він може припинити обговорення та повідомити про нові дані, які треба врахувати при вирішенні поставлених завдань, спрямувати обговорення в інше русло; оцінка результатів обговорення та підведення підсумків гри науково-педагогічним працівником та слухачем. Розігрування ролей $є$ достатньо ефективним методом вирішення організаційних та управлінських завдань [5].

В Національному університеті оборони України імені Івана Черняховського, м. Київ проводиться педагогічний експеримент щодо активізація навчання через зміну методики проведення навчальних занять в системі лідерських курсів:

лекція-дискусія - презентація навчального матеріалу, проведеного одним або декількома науково-педагогічними працівниками, після чого відбувається синдикатне завдання або обговорення матеріалу лекції та пов'язаних з ним попередніх читань. висновки за підсумками виконання завдання або дискусії синдикату представляються на пленарному засіданні 3 періодом запитань та відповідей;

робота в синдикаті - дискусія, яка базується на визначеному завданні або питаннях, за якими проводиться презентація рішення синдикату на пленарному засіданні або подання у письмовій формі науково-педагогічному працівнику;

семінар - брифінги або презентації після групової дискусії на основі попереднього вивчення матеріалу або дослідницьких проектів. мета - сприяння обміну думками, розвиток аналітичних компетентностей, критичного мислення, пошук нових ідей;

вправа - військовий аналіз ситуації у поєднанні 3 рольовим та інтерактивним застосуванням раніше вивченого матеріалу у форматованому та імітованому сценарії та синтезі зібраної та отриманої раніше інформації.;

командний дослідницький проект - дослідження проведене слухацькими групами 3 питань, пов'язаних 3 навчальною програмою курсу та в контексті історичного сценарію, дослідницького питання, аналітичного завдання (такого як тематичне дослідження або порівняльне дослідження або інша відповідна діяльність). складається 3 обов'язкового читання, обговорення, навчання та письмової роботи або презентації;

польове навчання (заняття на базі військ) - колективний візит до військової частини (установи), для надання досвіду та можливості вивчити раніше охоплені матеріали навчального плану (програми) у практичних умовах.

Практика свідчить, що найефективнішими є активні форми навчання та використання інноваційних технологій. Аналіз досвіду навчання військовоспеціальних дисциплін магістрантів свідчить, що застосування в освітньому процесі системи знань, що об'єднує імітацію, гру і проблемні ситуації, дозволяє 
надати навчальним заняттям пошукового характеру, захопити магістрантів самостійною пізнавальною діяльністю, перетворити їх на активних учасників навчання. Активні методи i прийоми викладання запобігають пасивному заучуванню слухачами фактичного матеріалу, сприяють розвитку творчих здібностей, самостійності, формуванню високого інтелектуального потенціалу.

Висновки. Активні методи навчання дають можливість активізувати у слухачів творчі здібності, розкриваючи їхній емоційно-інтелектуальний потенціал; формувати у них принципово важливі якості, які необхідні магістранту. Таким чином, можна стверджувати про доцільність і ефективність використання інноваційних технологій, активних форм навчання в процесі підготовки слухачів до майбутньої професійної діяльності. Це дозволяє озброїти магістрантів надійними знаннями, навичками та вміннями, адаптаційними механізмами до екстремальних факторів, забезпечити стійкість емоційновольової сфери, високий розвиток пошуково-дослідницьких компонентів діяльності та здатність коректувати реалізацію рішення залежно від мінливої ситуації. Проте варто зауважити, що вище зазначене не претендує на виключно вірне твердження - потрібно лише використовувати інтерактивне навчання. Воно потребує обов'язкового поєднання з традиційними у вищих військових навчальних закладах моделями та технологіями навчання i виховання та обираються науково-педагогічним працівником для застосування у тому випадку, коли таким шляхом можна забезпечити найвищі результати у навчальній діяльності слухачів. В подальшому пропонується удосконалення форм та методів активізації навчально-пізнавальної діяльності на основі впровадження інноваційних технологій навчання магістрантів, розробка засобів підвищення рівня засвоєння ними знань та практичних навичок, а також підвищення професійного рівня науково-педагогічного складу вищих військових навчальних закладів.

\section{ЛІТЕРАТУРА}

1. Нещадим М. І. Військова освіта України: історія, теорія, методологія, практика : [монографія] / Микола Іванович Нещадим. - К. : Видавничо-поліграфічний центр "Київський університет”, 2003. - 852 с.

2. Олійник Л.В. Методична система навчання військово-спеціальних дисциплін магістрів військово-соціального управління : [монографія] / Леонід Віталійович Олійник. Хмельницький : Видавництво НАДПСУ, 2017. - 340 с.

3. Олійник Л.В. Активні меоди навчання та їх роль у психолого-педагогічній підготовці майбутніх магістрів військово-соціального управління / Л. В. Олійник. // Теорія і практика управління соціальними системами // Щоквартальний науково-практичний журнал. - Харків : НТУ “ХПІ”, 2013. - № 4. - С. 51-57 (ISSN 2078-7782).

4. Ройлян В. О. Формування професійних якостей майбутніх фахівців сухопутних військ в умовах реформування вищої військової освіти : автореф. дис. на здобуття наук. ступеня канд. пед. наук : спец. 13.00.04 “Теорія та методика професійної освіти” / В. О. Ройлян. - Одеса, 2004. - 22 с.

5. Ягупов В.В. Теорія і методика військового навчання : [монографія] / Василь Васильович Ягупов. - К : Тандем, 2000. - 380 с. 
1. Neshchadym M. I. Viiskova osvita Ukrainy: istoriia, teoriia, metodolohiia, praktyka : [monohrafiia] / Mykola Ivanovych Neshchadym. - K. : Vydavnycho-polihrafichnyi tsentr "Kyivskyi universytet", 2003. - 852 s.

2. Oliinyk L. V. Metodychna systema navchannia viiskovo-spetsialnykh dystsyplin mahistriv viiskovo-sotsialnoho upravlinnia : [monohrafiia] / Leonid Vitaliiovych Oliinyk. Khmelnytskyi : Vydavnytstvo NADPSU, 2017. - 340 s.

4. Roilian V. O. Formuvannia profesiinykh yakostei maibutnikh fakhivtsiv sukhoputnykh viisk $\mathrm{v}$ umovakh reformuvannia vyshchoi viiskovoi osvity : avtoref. dys. na zdobuttia nauk. stupenia kand. ped. nauk : spets. 13.00.04 "Teoriia ta metodyka profesiinoi osvity" / V. O. Roilian. - Odesa, 2004. - 22 s.

5. Yahupov V. V. Teoriia i metodyka viiskovoho navchannia : [monohrafiia] / Vasyl Vasylovych Yahupov. - K : Tandem, 2000. - 380 s.

Леонид Олейник, кандидат педагогических наук, старший научный сотрудник Национальный университет обороны Украины имени Ивана Черняховского, г. Киев

\section{Активизация учебно-познавательной деяльностіи магистрантов в системе высшей военной школы}

В статье определяются направления исследования форм и методов активизаџии учебно-познавательной деятельности магистрантов. Анализируя внедрение инновационных технологий в изучение учебных предметов, установлено, что особенно актуальными эффективными являются коммуникативно-диалоговая и информационная технология обучения.

Ключевые слова: методы обучения; магистрант; учебно-познавательная деятельность; коммуникативно-диалоговая технология; информационная технология.

Leonid Oliynyk,

$\mathrm{PhD}$ (Candidate of pedagogical sciences, Senior research scientist) Senior research scientist of methodical and scientific center of educational activity organization of the National Defense University of Ukraine named after Ivan Chernyakhovskyi, c. Kyiv

\section{The activating of educational-cognitive activity masters on special high military school}

The ways of investigating the forms and methods of activating educational -cognitive activity on the basis of military and social management masters study analysis are defined in this article. Having been analyzed the invention of innovational technologies in the process of teaching special military subjects, it is set, the most actual and effective are communicative dialogue and informational.

The article deals with studying methods, its role, importance and its implementation possibilities during the didactic process in the higher military establishment. The methods and forms as basis for operational and procedural element of military and special subjects studying of military and social management masters are defined. The methods of studying of military and social management masters include: oral material delivering (studying materiel discussion), demonstration, exercises (training process), practice as well as self-studying.

We prove that the emphasis from passive forms of education should be shifted to the active forms and methods: seminars and workshops, discussions, simulation training and combat actions and situations of everyday activities, their review, analysis and evaluation.

According to the author, active learning methods provide intensive development of cognitive motives contributing to the manifestation of creative thinking of students, they aim to develop their creative independent thinking, learning and cognitive activation activity, the formation of skills and 
custom solutions professional military problems and improving the skills of professional communication.

The article reveals the essential content of the application of active learning methods. Found that it enables the future masters of military-social management to engage in purposeful process of development in their creative thinking that will professionally perform their tasks.

Key words: innovative technologies of teaching; educational-cognitive activity; communicative-dialogue technology; informational technology; masters. 